\title{
KARAKTERISTIK KIMIA TEPUNG SILASE LIMBAH IKAN TUNA (Thunnus sp.) DENGAN PENAMBAHAN TEPUNG JAGUNG
}

\author{
Chemical characteristics of Silage Flour from Tuna Fish Waste (Thunnus sp.) with corn flour addition
}

\author{
Safitra ${ }^{*}$, Asnani ${ }^{1}$, Sri Rejeki² \\ 1Jurusan Teknologi Hasil Perikanan, Fakultas Perikanan dan Ilmu Kelautan Universitas Halu Oleo, Kendari, \\ Sulawesi Tenggara, Indonesia \\ 2Jurusan IImu dan Teknologi Pangan, Fakultas Pertanian Universitas Halu Oleo, Kendari, Sulawesi Tenggara, \\ Indonesia \\ *Email korespondensi: fhytrasafitra2297@gmail.com (Telp: +6282187725525) \\ Diterima: 9 Januari/ Disetujui 10 Maret 2020
}

Cara sitasi: Safitra, Asnani, Rejeki S. 2020. Karakteristik kimia tepung silase limbah ikan tuna (Thunnus sp.) dengan penambahan tepung jagung. Jurnal Fish Protech. 3(1):74-78.

\section{ABSTRACT}

The purpose of this study was to determine the chemical characteristics and the effect of the addition of corn flour to tuna waste silage flour. This study used a Completely Randomized Design (CRD) consisting of four treatments, namely TS1 (5\% addition to corn flour), TS2 (10\% adding corn flour), TS3 (15\% adding corn flour), TS4 (20\% adding corn flour) ) and repeat three times. Data from observations were analyzed using ANOVA (Analysis of Variance) at a level of 95\%, if there is a real difference $(P>0.05)$ then a further test was performed with a DMRT (Duncan Multiple Range Test) test at a 95\% level. The results showed that the effect of adding corn flour to fish waste silage flour had a significant effect on the chemical content test value. The results of the chemical test of the silage flour show water content between $10.4 \%-8.4 \%$, ash content of $24.2 \%-7.9 \%$, protein content of $47.5 \%-43.3 \%$, and fat content of $4.6 \%-2.1 \%$.

Keywords: Silage flour, tuna waste (Thunnus sp.), Corn flour (maizenaku) and proximate composition.

\section{ABSTRAK}

Tujuan penelitian ini adalah untuk mengetahui karakteristik kimia dan pengaruh penambahan tepung jagung pada tepung silase limbah ikan tuna. Penelitian ini menggunakan Rancangan Acak Lengkap (RAL) yang terdiri dari empat perlakuan yaitu perlakuan TS1 (5\% penambahan tepung Jagung), TS2 (10\% penambahan tepung jagung), TS3 (15\% penambahan tepung jagung), TS4 (20\% penambahan tepung jagung) dan ulangan sebanyak tiga kali. Data hasil pengamatan dianalisa menggunakan ANOVA (Analysis of Variance) pada taraf $95 \%$, apabila terdapat beda nyata $(P>0,05)$ maka dilakukan uji lanjut dengan uji DMRT (Duncan Multiple Range Test) pada taraf nyata 95\%. Hasil penelitian yang diperoleh menunjukkan bahwa pengaruh penambahan tepung jagung pada tepung silase limbah ikan memberikan pengaruh nyata terhadap nilai uji kandungan kimia. Hasil uji kandungan kimia tepung silase menunjukkan kadar air antara $10,4 \%-8,4 \%$, kadar abu $24,2 \%-7,9 \%$, kadar protein $47,5 \%-43,3 \%$, dan kadar lemak 4,6\%-2,1\%.

Kata kunci: Tepung silase, limbah ikan tuna (Thunnus sp.), tepung jagung (maizenaku) serta komposisi proksimat

\section{PENDAHULUAN}

Ikan tuna (Thunnus sp.) merupakan salah satu komoditas perikanan Indonesia yang memiliki nilai ekonomis tinggi dan mampu menembus pasar internasional. Potensi ikan tuna di perairan Indonesia masih cukup besar. Volume ekspor ikan tuna dan cakalang pada tahun 2015 mencapai 1.070 .871 ton (Firdaus, 2018). Menurut Supriyanto (2015) limbah yang dihasilkan dari kegiatan perikanan masih cukup tinggi, yaitu sekitar 20-30\%. Jika jumlah ekspor ikan tuna dan cakalang sebesar 1.070 .871 ton pertahun 
maka limbah yang dihasilkan sekitar \pm 214 - \pm 321 ton pertahun. Salah satu alternatif pemanfaatan ini adalah dengan membuat produk tepung silase dengan pemanfaatan ini akan mengurangi dampak buruk pencemaran lingkungan akibat dari pembuangan limbah industri pengolahan tuna (Trilaksani et al., 2006).

Pembuatan silase ikan di Indonesia telah berkembang dan dikenal dua cara pembuatan silase yaitu secara kimiawi dan secara biologis melalui proses fermentasi. Pembuatan secara kimiawi menggunakan penambahan asam kuat baik asam mineral (asam anorganik) maupun asam organik, sedangkan pembuatan secara biologi yaitu memanfaatkan mikroba tertentu dengan menambahkan bahan seperti EM4 (Effective Microorganisme 4). Penggunaan kultur campuran mikroorganisme pada saat ini banyak dilakukan, salah satunya adalah menggunakan kultur EM-4. Menurut Higa dan Parr (1995) di dalam kultur EM-4 mengandung sekitar 80 genus, diantaranya lima kelompok mikroorganisme utama, yaitu golongan ragi, Lactobacillus, jamur fermentasi, bakteri fotosintetik,

\section{METODE PENELITIAN}

\section{Alat dan Bahan}

Alat yang digunakan dalam penelitian ini adalah toples kaca, pisau, labu ukur, pipet tetes dan blander (Miyako), pengaduk, alat titrasi, cawan porselin (Pyrex), desikator, Erlenmeyer (Pyrex), gelas beaker, gelas ukur (Pyrex), hot plate, inkubator, labu kjedahl,

\section{Prosedur Penelitian}

Tabel 1. Perlakuan tepung silase ikan tuna dengan penambahan tepung jagung yang berbeda

\begin{tabular}{lcccc}
\hline \multirow{1}{*}{ Bahan } & \multicolumn{4}{c}{ Formulasi (\%) } \\
\cline { 2 - 5 } & TS1 & TS2 & TS3 & TS4 \\
\hline Limbah ikan tuna & 75 & 70 & 65 & 60 \\
Tepung jagung & 5 & 10 & 15 & 20 \\
EM4 & 15 & 15 & 15 & 15 \\
Asam format & 4 & 4 & 4 & 4 \\
Soda abu & 1 & 1 & 1 & 1 \\
\hline
\end{tabular}

dan Actinomycetes, aktivitasnya bersifat fermentasi dan sintetik. Lactobacillus dalam EM-4 merupakan bakteri asam laktat yang dapat dimanfaatkan dalam pembuatan silase. Heinritz (2011) mengemukakan bahwa bakteri asam laktat dalam ensilase dapat mengubah karbohidrat yang mudah larut menjadi asam laktat, sehingga kandungan asam laktat substratnya meningkat, akibatnya proses ensilase berjalan dengan baik.

Tepung jagung merupakan bahan tambahan yang dapat digunakan dalam pembuatan silase sebagai sumber karbohidrat terlarut. Menurut Malalantang (2015) bahwa penambahan tepung jagung dapat meningkatkan kualitas fisik silase rumput gajah dan dapat meningkatkan tingkat kesukaan yang ditunjukkan oleh ternak untuk mengkonsumsi suatu bahan pakan yang diberikan dalam suatu waktu (palatabilitas) dan kecernaan bahan pakan pada ternak. Tepung jagung memiliki kandungan gizi seperti protein kasar $(8,78 \%)$, serat kasar $(3,12 \%)$, kadar lemak $(4,92 \%)$, kadar air (10\%), dan kadar abu $(2,01 \%)$ (Suarni dan Firmansyah, 2005).

muffle furnance, $\mathrm{pH}$ meter, soxlet, tabung reaksi, neraca analitik, dan autoclave.

Bahan yang digunakan dalam penelitian ini adalah Bahan-bahan yang digunakan dalam penelitian ini adalah limbah ikan tuna (kepala, insang dan jeroan) yang diperoleh dari Tempat Pelelangan Ikan (TPI), tepung jagung (maizenaku), akuades, asam format $85 \%$, soda abu ( $\left.\mathrm{Na}_{2} \mathrm{CO}_{2}\right)$, EM-4, $\mathrm{K}_{2} \mathrm{SO}_{4}, \mathrm{HgO}, \mathrm{H}_{3} \mathrm{BO}_{3}$, $\mathrm{NaOH}, \mathrm{H}_{2} \mathrm{SO}_{4}, \mathrm{HCl}$, dan alkohol.

Proses pembuatan silase ikan menurut modifikasi Rachamawati dan Nopianti (2013) cara pembuatan silase ikan adalah bahan baku limbah ikan tuna (kepala,insang, dan jeroan) dicuci bersih lalu ditiriskan. selanjutnya limbah ikan Tuna dihaluskan dengan blender, kemudian ditimbang sebanyak $300 \mathrm{~g}$. Limbah ikan Tuna dimasukkan ke dalam toples kaca kemudian diberi bahan tambahan sebanyak $20 \%$ yang terdiri dari: Em4 15\%, asam format 4\% dan soda abu $1 \%$, tepung jagung sesuai konsentrasi (seperti pada Tabel 1). Kemudian campuran limbah ikan diaduk 
hingga merata kemudian dilakukan pengukuran $\mathrm{pH}$ sebelum fermentasi. Sampel difermentasi selama 9 hari. Setelah fermentasi, $\mathrm{pH}$ silase diukur sampai netral dengan soda abu sebanyak $1 \%$ dari bahan baku, kemudian diaduk hingga merata, selanjutnya dilakukan pengeringan menggunakan oven suhu $50^{\circ} \mathrm{C}$ selama 50 jam lalu digiling kemudian diayak (80 mesh) menjadi tepung silase.

\section{HASIL DAN PEMBAHASAN}

\section{a. Kadar air}

Tabel 2. Rerata nilai kadar air pada tepung silase

\begin{tabular}{llll}
\hline Perlakuan & $\begin{array}{l}\text { Kadar Air } \pm \\
\text { SD }\end{array}$ & DMRT $_{0,05}$ & SNI \\
\hline TS1 & $10,4 \pm 0,17^{\mathrm{c}}$ & $2=0,32$ & Tepung \\
TS2 & $10,2 \pm 0,04^{\mathrm{c}}$ & $3=0,33$ & Ikan \\
TS3 & $9,6 \pm 0,41^{\mathrm{b}}$ & $4=0,33$ & Maks \\
TS4 & $8,4 \pm 0,05^{\mathrm{a}}$ & $5=0,35$ & $12 \%$ \\
\hline
\end{tabular}

Keterangan: Formulasi limbah ikan, tepung jagung, dan bahan tambahan (EM4,Asam format, dan soda abu) berturut-turut: 75:5:20 (TS1), 70:10:20 (TS2), 65:15:20 (TS3), 60:20:20 (TS4)

Air merupakan kandungan terbesar di dalam tubuh ikan. Air merupakan komponen yang penting bagi bahan pangan karena air dapat mempengaruhi kenampakan dan tekstur pada makanan. Kadar air menjadi salah satu faktor penyebab kerusakan bahan pangan, karena air merupakan media pendukung aktivitas mikroba pembusuk (Majid, 2014).

Hasil pengujian kadar air tepung silase pada penelitian ini memiliki nilai rata-rata tertinggi terletak pada perlakuan TS1 dengan nilai $10,4 \%$ dan nilai ratarata terendah diperoleh dari perlakuan TS4\% dengan nilai 8,4 . Hal ini diduga karena dipengaruhi oleh konsentrasi penambahan limbah ikan pada silase dimana semakin rendah kosentrasi limbah ikan maka semakin rendah kadar air tepung silase. Kandungan kadar air tertinggi terdapat pada perlakuan TS1, hal ini diduga karena limbah ikan tuna yang digunakan memiliki kadar air sekitar 4,86\% sedangkan tepung jagung memiliki kadar air lebih rendah sekitar $4,30 \%$. Kandungan kadar air yang relatif rendah akan membuat masa simpan tepung silase lebih tahan

\section{Parameter uji}

Analisis komposisi proksimat tepung silase limbah ikan tuna (Thunnus sp.) meliputi kadar air (AOAC 2005), kadar lemak (AOAC 2005), kadar protein (AOAC 2005), dan kadar lemak (AOAC 2005)

lama. Menurut Krishaditersantoso (2013), kadar air yang terlalu tinggi akan menyebabkan tepung silase busuk. Hasil nilai uji kadar air pada penelitian ini lebih rendah dari penelitian Jayanti et al. (2018) dihasilkan nilai kadar air yang tinggi berkisar antara 11,25\%$11,61 \%$. Nilai kadar air tepung silase limbah ikan pada penelitian ini memenuhi nilai SNI tepung ikan pada pakan, dimana SNI tepung ikan pada pakan maksimal 12\% (SNI 01-2715-1996).

\section{b. Kadar Abu}

Tabel 3. Rerata nilai kadar abu pada tepung silase

\begin{tabular}{llll}
\hline Perlakuan & $\begin{array}{l}\text { Kadar Abu } \pm \\
\text { SD }\end{array}$ & DMRT $0,05^{\text {SNI }}$ & \\
\hline TS1 & $24,2 \pm 0,17^{\mathrm{d}}$ & $2=0,32$ & Tepung \\
TS2 & $19,5 \pm 0,06^{\mathrm{c}}$ & $3=0,33$ & Ikan \\
TS3 & $14,1 \pm 0,35^{\mathrm{b}}$ & $4=0,33$ & Maks \\
TS4 & $7,9 \pm 0,28^{\mathrm{a}}$ & $5=0,35$ & $25 \%$
\end{tabular}

Keterangan: Formulasi limbah ikan, tepung jagung, dan bahan tambahan (EM4,Asam format, dan soda abu) berturut-turut: 75:5:20 (TS1), 70:10:20 (TS2), 65:15:20 (TS3), 60:20:20 (TS4)

Kadar abu atau mineral merupakan bagian serta mineral dari bahan yang didasarkan atas berat keringnya. Abu yaitu zat yang tidak menguap, sisa dari proses pembakaran atau hasil oksidasi (Winarno, 2002).

Hasil pengujian kadar abu tepung silase pada penelitian ini memiliki nilai rata-rata tertinggi terletak pada perlakuan TS1 dengan nilai $24,2 \%$ dan nilai ratarata terendah terletak pada perlakuan TS4 sebesar $7,9 \%$. Hal ini diduga karena dipengaruhi oleh kosentrasi penambahan limbah ikan pada silase 
dimana semakin rendah kosentrasi limbah ikan maka semakin rendah kadar abu tepung silase. Kandungan kadar abu tertinggi terdapat pada perlakuan TS1, hal ini diduga karena limbah ikan tuna yang digunakan memiliki kadar abu sekitar 2,9\% sedangkan tepung jagung memiliki kadar abu lebih rendah sekitar 1,86\%. Hasil nilai kadar abu pada penelitian ini lebih rendah dari penelitian Supriyanto et al. (2015) dihasilkan nilai kadar abu yang tinggi berkisar antara 7,49\%-23,09\%. Nilai kadar abu tepung silase limbah ikan pada penelitian ini memenuhi nilai SNI tepung ikan pada pakan, dimana SNI tepung ikan pada pakan maksimal 25\% (SNI 01-2715-1996).

\section{c. Kadar Protein}

Tabel 4. Rerata nilai kadar protein pada tepung silase

\begin{tabular}{llll}
\hline Perlakuan & $\begin{array}{l}\text { Kadar } \\
\text { Protein } \pm \text { SD }\end{array}$ & DMRT $0,05^{\text {SNI }}$ & \\
& & \\
\hline TS1 & $47,5 \pm 0,42^{\mathrm{d}}$ & $2=0,65$ & Tepung \\
TS2 & $46,4 \pm 0,24^{\mathrm{c}}$ & $3=0,67$ & lkan Min \\
TS3 & $44,6 \pm 0,42^{\mathrm{b}}$ & $4=0,67$ & $55 \%$ \\
TS4 & $43,3 \pm 0,42^{\mathrm{a}}$ & $5=0,70$ & \\
\hline
\end{tabular}

Keterangan: Formulasi limbah ikan, tepung jagung, dan bahan tambahan (EM4,Asam format, dan soda abu) berturut-turut: 75:5:20 (TS1), 70:10:20 (TS2), 65:15:20 (TS3), 60:20:20 (TS4)

Hasil pengujian kadar protein tepung silase pada penelitian ini memiliki nilai rata-rata tertinggi terletak pada perlakuan TS1 dengan nilai $47,5 \%$, dan nilai rata-rata terendah diperoleh dari perlakuan TS4 dengan nilai $43,3 \%$. Kadar protein pada penelitian ini berbeda jauh dari hasil penelitian yang telah dilakukan oleh Nahak et al. (2019) pada tepung silase berbasis sorgum dengan penambahan tepung jagung yang memiliki nilai kadar protein sebesar $12,30 \%$. Namun, tidak berbeda jauh dari hasil penelitian yang telah dilakukan oleh Supriyanto et al. (2015) pada tepung silase limbah ikan gabus dengan penambahan tepung kiambang dengan nilai kadar protein sebesar $20,62 \%$ $-32,71 \%$. Nilai kadar protein tepung silase limbah ikan pada penelitian ini belum memenuhi nilai SNI tepung ikan pada pakan, dimana SNI tepung ikan pada pakan minimal 55\% (SNI 01-2715-1996).

\section{d. Kadar Lemak}

Tabel 5. Rerata nilai kadar lemak pada tepung silase

\begin{tabular}{llll}
\hline Perlakuan & $\begin{array}{l}\text { Kadar } \\
\text { Lemak } \pm \text { SD }\end{array}$ & DMRT $0,05^{\text {SNI }}$ & \\
\hline TS1 & $2,1 \pm 0,16^{\mathrm{a}}$ & $2=0,32$ & Tepung \\
TS2 & $2,5 \pm 0,11^{\mathrm{a}}$ & $3=0,33$ & lkan \\
TS3 & $3,5 \pm 0,38^{\mathrm{a}}$ & $4=0,33$ & Maks \\
TS4 & $4,6 \pm 0,26^{\mathrm{b}}$ & $5=0,35$ & $10 \%$ \\
\hline
\end{tabular}

Keterangan: Formulasi limbah ikan, tepung jagung, dan bahan tambahan (EM4,Asam format, dan soda abu) berturut-turut: 75:5:20 (TS1), 70:10:20 (TS2), 65:15:20 (TS3), 60:20:20 (TS4)

Lemak merupakan zat makanan yang penting bagi tubuh dan merupakan sumber energi yang lebih efektif (Rengi dan Sumarto, 2014).

Hasil penelitian menunjukkan bahwa nilai rata-rata kadar lemak tertinggi diperoleh dari perlakuan TS4 sebesar 4,6\% dan nilai rata-rata terendah terletak pada perlakuan TS1 sebesar 2,1\% diketahui bahwa rata-rata nilai kadar lemak terhadap perlakuan yang diberikan dapat meningkatkan nilai kadar lemak pada tepung silase. Namun, tidak berbeda jauh dari hasil penelitian yang telah dilakukan oleh Supriyanto et al. (2015) pada tepung silase limbah ikan gabus dengan penambahan tepung kiambang dengan nilai kadar protein sebesar 3,84\%$2,84 \%$. Nilai kadar lemak tepung silase limbah ikan pada penelitian ini memenuhi nilai SNI tepung ikan pada pakan, dimana SNI tepung ikan pada pakan maksimal 10\% (SNI 01-2715-1996).

\section{KESIMPULAN}

Kesimpulan dari hasil penelitian ini adalah:

1. Karakteristik kimia tepung silase limbah ikan Tuna di peroleh hasil terbaik pada penambahan tepung jagung $5 \%$ dengan nilai kadar protein $47,5 \%$ dan kadar lemak 2,1\%. Kadar air dan kadar abu terbaik terdapat pada tepung silase dengan penambahan tepung jagung 20\% dengan nilai berturut-turut $8,4 \%$ dan $7,9 \%$.

2. Penambahan kosentrasi jagung berpengaruh nyata terhadap kadar air, kadar protein, kadar lemak, dan kadar abu tepung silase. 


\section{DAFTAR PUSTAKA}

AOAC. 2005. Official Methods of Analysis. 18th ed. Association of Official Analytical Chemists, Washington DC.

Firdaus M. 2018. Profil Perikanan Tuna dan Cakalang di Indonesia. Balai Beasr Riset Sosial Ekonomi Kelautan dan Perikanan. Jakarta Utara.

Heinritz, S. 2011. Ensiling Suitability of High Protein Tropical Forages and Their Nutritional Value For Feeding Pigs. Diploma Thesis. University of Hohenheim. Stuttgar.

Higa, T. and Parr, JF. 1995. Beneficial and Microorganisms for Sustainable Agriculture and Environment. Soil Microbiologist Agricultural Research Service, US. Department of Agriculture Beltsville. Maryland.

Jayanti. D.Z, Herpandi dan Lestari. D. S. 2018. Pemanfaatan limbah ikan menjadi tepung silase dengan penambahan tepung eceng gondok (eichhornia crassipes). Jurnal Teknologi hasil perikanan. Universitas Sriwijaya. Vol. 7. No. 1:86-97.

Krishaditersantoso, R. 2013. Membuat Silase. Kupang Tengah, NNT.

Majid, A., Tri W.A., dan Laras R. 2014. Pengaruh Perbedaan Konsentrasi Garam terhadap Mutu Sensori dan Kandungan Senyawa Volatil pada Terasi Ikan Teri (Stolephorus sp.). Jurnal Pengolahan dan Bioteknologi Hasil Perikanan. 3(2): 17-24.

Malantang S.S, Tulung Y.R. L, Rustandi, kojo R.M. 2015. Pengaruh Penambahan Dedak Padi Dan Tepung Jagung Terhadap Kualitas Fisik Silase Rumput Gajah (Pennisetum Purpureumcv Hawaii). Jurnal Zootek. Vol. 35 No. 1:21-29 Januari 2015. ISSN 0852-2626.
Nahak. O.R., P.K. Tahukb., G.F. Birac., A. Bered dan H. Riberue. 2019. Pengaruh Penggunaan Jenis Aditif yang Berbeda Terhadap Kualitas Fisik dan Kimia Silase Komplit Berbahan Dasar Sorgum (Shorgum bicolor (L.) Moench) J. Anim. Sci. 4(1):3-5.

Rachmawati SH, Nopianti R. 2013. Fermentasi Silase Limbah Ikan Gabus (Channa striata) dengan Menggunakan Metode Kimia dan Mikrobiologi. Makalah seminar Nasional dan Rapat Tahunan Dekan Bidang IImu-IImu Pertanian BKS-PTN Wilayah Barat. Inderalaya, 19-20 Maret.

Standarisasi Nasional Indonesia. 1996. Standar Nasional Tepung Ikan. SNI 01-27151996/Rev.92.

Suarni dan Firmansyah I.U. 2005. Beras Jagung; Prosessing Dan Kandungan Nutrisi Sebagai Bahan Pangan Pokok. Prosiding Seminar Dan Lokakarya Nasional.393-398.

Supriyanto A, Baehaki A, Hanggita S. 2015. Karakteristik Fisik dan Kimia Tepung Silase Limbah Ikan Gabus (Channa striatai) Dengan Penambahan Konsentrasi Tepung Kiambang Terfermentasi. Skripsi. Fakultas Pertanian. Universitas Sriwijaya.

Trilaksani W, Salamah E, dan Nabil M. 2006. Pemanfaatan Limbah Ikan Tulang Ikan Tuna (Thunnus sp.) Sebagai Sumber Kalsium Dengan Metode Hidrolisis Protein. Jurnal Departemen Teknologi Hasil Perairan, FPIK. IPB. Vol IX Nomor 2.

Winarno, FG. 2002. Kimia Pangan dan Gizi. Gramedia. Jakarta. 